\title{
Control of the Regioselectivity in the Enzymatic Syntheses of Oligosaccharides Using Glycosidases
}

\author{
加水分解酵素を利用したオリゴ糖合成における位置選択性のコントロール
}

\author{
Ajisaka, Katsumi ; and Yamamoto, Yuichi \\ Meiji Dairies Co., 540 Naruda, Odawara, Kanagawa 250-0862, Japan. \\ FAX : 81-465-36-2776, E-mail:kajisaka@mbc.sphere.ne.jp
}

Key Words : glycosidase, transglycosylation, regioselectivity

\begin{abstract}
There are two strategies for the enzymatic synthesis of oligosaccharides; the use of glycosidases and the use of transferases. The reaction using glycosidases can be further classified into two methods; the transglycosylation and the reverse hydrolysis reaction. In this review, I would like to summarize and discuss these by focusing on the regioselectivity in the synthesis of oligosaccharides by the transglycosylation and reverse hydrolysis reaction.
\end{abstract}

\section{A. Introduction}

Glycosidases have been widely utilized in the food industry as a tool for the hydrolysis of polysaccharides or oligosaccharides (1). Furthermore, glycosidases are also used industrially for the synthesis of oligosaccharides by a reversal of the hydrolysis reaction, in the production of food additives (2). However, these industrially produced oligosaccharides are a mixture of various linkages, regioselective synthesis not being given attention until recently. Presently, on the other hand, the reaction using glycosidases is thought to be not as suitable for the synthesis of oligosaccharides of a specific linkage with high regioselectivity as the reaction using transferases. Moreover, the low yield of the reaction is another demerit of the reaction using glycosidases (3). Still, the oligosaccharide synthesis using glycosidase has a merit that not only substrates but also enzymes are relatively cheap. For such reasons, we have studied the reaction using glycosidases in order to establish a new methodology for highly regioselective syntheses of oligosaccharides.

Many review articles have been published about oligosaccharide synthesis with the aid of glycosidases (4-7). In this review, I would mainly like to discuss how to obtain oligosaccharides regioselectively and in high yield, drawing upon the results of my research. The reaction using glycosidases can be classified into two approaches; transglycosylation and reverse hydrolysis reaction. It would appear that the most direct way to achieve the synthesis of oligosaccharides of specific linkages is to clarify what is controlling the regioselectivity in these two reactions. First I will demonstrate the relation between the hy-
要 約

酵素を利用したオリゴ糖合成には、加水分解酵素の逆反応 を利用する方法と、糖転移醰素(トランスフェラーゼ)を利用する 方法の 2 種類の方法がある。さらに、加水分解酵素を利用した オリゴ糖合成法はメカニズムの面から転移反応とリバースハイ ドロリシス反応とに分類される。本稿では、加水分解酵素を用 いた 2 種類の反応、即ち転移反応とリバースハイドロリシス反 応について概説し、更に如何にして目的とするオリゴ糖を位置 選択的に得るかという部分に焦点をあてて、我々がこれまでに 明らかにしてきた知見を中心にして解説する。

\section{A. 序 論}

糖加水分解酵素とは、その名のごとくオリゴ糖あるいは多 糖を加水分解する酵素であり、これまでにも主として食品産業 において広く利用されている(1)。一方加水分解とは逆の作用で あるオリゴ糖を合成するという機能を利用して、食品用オリゴ 糖の製造を目的として工業的にも利用されている(2)。しかしそ のような食品用オリゴ糖の生産において得られるオリゴ糖はい ろいろな結合のオリゴ糖の混合物であり、位置選択的な合成と いう点にはあまり注意が払われて来なかった。そのために加水 分解酵素を利用したオリゴ糖合成反応はトランスフェラーゼを 利用した合成法に比べて位置選択性が低く、ある特定の結合の オリゴ糖を位置選択的に合成するといった目的には適さない、 と言われてきた。また、加水分解酵素を利用したオリゴ糖合成 法は反応収率が低いということも欠点の一つとされてきた(3)。 そ机に対して加水分解酵素を利用したオリゴ糖合成法は、基質 が安価で、酵素も比較的安価且つ容易に入手できるというメ リットを有している。そのような理由から、我々は加水分解酵 素を用いる反応をオリゴ糖の精密合成に利用することを目的と して研究を続けてきた。

これまでに、加水分解酵素を利用したオリゴ糖合成反応に 関しては数多くの総説が発表されている(4-7)。本稿では、我々 が行ってきた研究を中心として、加水分解酵素を利用したオリ ゴ糖合成反応に於いて、如何にして目的とする結合のオリゴ糖 を高い収率で得るかという部分に焦点を当てて解説する。加水 分解酵素を利用したオリゴ糖合成反応は、反応方法の違いによ り転移反応とリバースハイドロリシス反応という 2 つの方法に 分けられる。従って、これらの反応における位置選択性はどの ようにコントロールされているかを解明することが、位置選択 
drolysis specificity of glycosidase and the regioselectivity in the synthesis of oligosaccharides. Then I would like to discuss how to obtain the oligosaccharides of target linkages.

\section{B. Transglycosylation and Reverse Hydrolysis Reaction}

In Fig. 1, transglycosylation and reverse hydrolysis reaction are schematically demonstrated. In the synthesis of lactose using $\beta$-galactosidase, Gal- $\beta$-pNP 1 binds with $\beta$-galactosidase to form an active intermediate enzyme-substrate 2 . If water molecule attacks this intermediate, galactose $\mathbf{3}$ will be formed. In contrast, if glucose molecule $\mathbf{4}$ attacks this intermediate, galactosyl-glucose 5 will be formed. In this case, the reaction is called "a transglycosylation". The linkage between galactose and glucose depends on the nature of the enzyme.

Here, it should be noted that an equilibrium exists between $\mathbf{2}$ and $\mathbf{3}$; the intermediate $\mathbf{2}$ can be formed from galactose 3 and enzyme in the aqueous solution. In this case, galactosyl glucose will be formed if glucose molecules are also present in the solution in high concentration. Thus the reaction to produce disaccharide $\mathbf{5}$ from monosaccharide $\mathbf{3}$ via intermediate $\mathbf{2}$ is called "a reverse hydrolysis reaction". However the process generating 2 from 3 is generally very slow since the equilibrium constant of the reaction is very small, and consequently the yield of disaccharide 5 from $\mathbf{3}$ and $\mathbf{4}$ is very small. However, disaccharide 5 can be obtained from galactose 3 and glucose 4 by controlling the reaction condition.

\section{Reverse Hydrolysis Reaction}

As shown in Fig. 1, the reverse hydrolysis reaction is called a "condensation reaction" because of its style of reaction. In Fig. 1, the hydrolysis reaction of $\mathbf{5}$ to form monosaccharides
的合成への近道でもあろう。そこでまず、加水分解酵素の基質 特異性と生成物の位置選択性の関倸について解説し、さらに如 何にして目的の結合を持ったオリゴ糖を選択的に合成するかと いう点に焦点をあてて議論したい。

\section{B. 転移反応とリバースハイドロリシス反応}

転移反応とリバースハイドロリシス反応の関倸を、 $\beta$-ガラ クトシダーゼを利用したラクトースの合成反応を例として図 1 に示す。パラニトロフェニル- $\beta$-D-ガラクトピラノシド(Gal- $\beta$ pNP) 1 が $\beta$-ガラクトシダーゼと結合して基質-酵素活性中間体 2を生成する。これに水分子が攻撃するとガラクトース 3 にな る。この場合、現象としては加水分解が起こったことになる。 一方、これにグルコース 4 が攻撃するとラクトース5が生成す る。これが転移反応である。この場合必ずしも $\beta 1-4$ 結合のラク トースが生成するとは限らず、どのような結合の 2 糖が生成す るかは酵素の性質によって規定される。

ここで、 2 と $\mathbf{3}$ の間の反応も平衡反応であり、水溶液中で はガラクトース 3 から基質-酵素活性中間体 2 が生成する。この 場合にも溶液中にグルコースが存在すればラクトース 5が生成 する。このように単糖 $\mathbf{3}$ から活性中間体 $\mathbf{2}$ を経て 2 糖 $\mathbf{5}$ が生成 する反応がリバース八イドロリシス反応である。一般に平衡定 数の関係から 3 から 2 が生成する割合は極めて低く、従って 3 から 2 を経てラクトース 5 が生成する割合も少ないが、原理的 にはガラクトース 3 とグルコース 4 からラクトース 5 を合成す ることは可能である。

\section{C. リバースハイドロリシス反応}

図1に示されるように、リバースハイドロリシス反応は現 象的には加水分解の逆であることから縮合反応と呼ばれること もある。図 1 において、2 糖 $\mathbf{5}$ が加水分解されて単糖の $\mathbf{3}$ およ

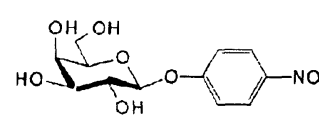

1

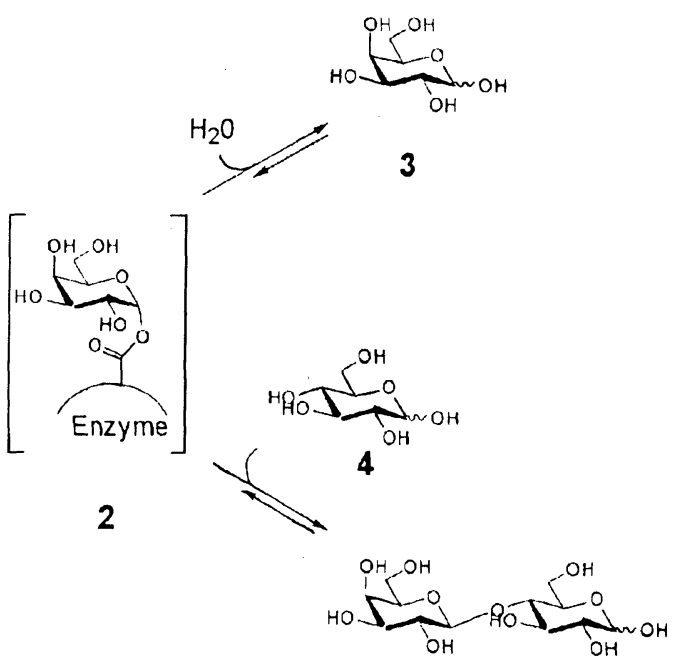

5

Fig. 1. Action of $\beta$-galactosidase on para-nitrophenyl- $\beta$-D-galactopyranoside in an aqueous solution. 
3 and $\mathbf{4}$ is catalyzed by an enzyme, but actually this reaction can occur even without enzymes. Namely, the bond between galactose and glucose in lactose is an acetal bond, which means that equilibrium exists between lactose, galactose, and glucose. Therefore, the hydrolysis of lactose or the condensation of two monosaccharides can proceed without an enzyme in principle, but actually no reaction occurs in the natural state without an enzymes since the activation energy between lactose and two monosaccharides is very high. Enzymes work to lower the activation energy for reactions between lactose and its two monosaccharides. Moreover, the hydrolysis reaction is usually observed in the dilute substrate solution, and in contrast the reverse hydrolysis reaction occurs in a solution of high substrate concentration.

Next, examples of the reverse hydrolysis using glucose as a substrate were investigated. In the reaction of highly concentrated glucose solution in the presence of $\alpha$-glucosidase, many oligosaccharides are formed including $\alpha 1-2-, \alpha 1-3-, \alpha 1-$ $4-$, and $\alpha 1-6$-linked disaccharides and, with further condensation, trisaccharides (8). In Table I, the yields of disaccharides are shown together with standard free energies obtained from literature on this subject (9). The standard free energy of $\alpha 1-6-$ linked disaccharide is the lowest, and the yield of this disaccharide is highest in contrast. The $\alpha 1-\alpha 1$-linked disaccharide, trehalose, exhibited the highest standard free energy and was not detected at all. It is noteworthy that the standard free energy and the yield of disaccharides are in reverse correlation. Fig. 2 shows schematically the standard free energy of disaccharides and the activation energy of reactions between monosaccharides and disaccharide. The yield of disaccharides by reverse hydrolysis reaction is highly correlated with the standard free energy, the activation energy needed to form the enzyme-substrate intermediate not being a factor. Therefore the reverse hydrolysis reaction is called an "equilibrium-controlled reaction".

In the acid catalyzed condensation reaction of highly concentrated glucose solution, disaccharides are formed with similar composition. However, in this case, isomers with $\beta$-linkages
び4になる反応では酵素が介在しているが、実際にはこの反応 は酵素が存在しなくても進行する。即ち、2 糖 $\mathbf{5}$ におけるガラ クトースとグルコースの間の結合はアセタール結合であり、水 溶液中では $2 つ の$ 単糖とラクトースは平衡状態にある。従って 原理的には酵素が存在しなくてもラクトースからグルコースと ガラクトース、あるいはグルコースとガラクトースからラク トースへの反応は進行するはずであるが、現実にはその間の活 性化エネルギーが大きいために、自然な状態でどちらかに移動 するということはない。酵素はこの平衡反応の活性化エネル ギーを低下させ、その往き来を容易にする役割を果たしてい る。また、酵素の存在下で 2 糖から単糖への加水分解が観測さ れるのは、基質が希薄な水溶液中での話である。逆に濃厚な溶 液中では逆方向の反応、即ち脱水縮合反応により単糖から 2 糖 が生成する反応 (リバースハイドロリシス反応)が目に見えて多 くなる。

次に、グルコースを原料としたリバースハイドロリシス反応 の例を示す。グルコースの濃厚溶液に $\alpha$-グルコシダーゼを添加 して反応を行うと、 $\alpha 1-2$ 結合、 $\alpha 1-3$ 結合、 $\alpha 1-4$ 結合、 $\alpha 1-6$ 結合 の 2 糖、さらにはそれらにさらにグルコースが結合した 3 糖な ど多数のオリゴ糖が生成してくる(8)。表 1 に 2 糖に関してのみ ではあるがリバースハイドロリシス反応における生成物の収率 を示した。また表 1 には文献值(9)として標準自由エネルギーの 值も示した。標準自由エネルギーの低い $\alpha 1-6$ 結合の 2 糖の収率 が最も高く、標隼自由エネルギーが最も大きい $\alpha 1-1$ 結合の 2 糖 は検出されなかった。その他の 2 糖も標準自由エネルギーの值 に反比例した収率で生成している。図 2 に、この反応における 各物質の標準自由エネルギーと基質-酵素活性中間体から 2 糖が 生成する際の遷移状態のエネルギー障壁の高さを模式的に図示 した。図 2 示すように、リバースハイドロリシス反応に拀ける 生成物の収率は、 2 糖が生成する際のエネルギー障壁の高さに よるのではなく、最終生成物の標準自由エネルギーの值に依存 する。このようなことから、リバースハイドロリシス反応は Equilibrium controlled reactionとも呼ばれている。

データとしては示さなかったが、グルコースの高濃度溶液に 酸を加えて加熱しても脱水縮合反応によりオリゴ糖が生成す る。この場合には $\alpha$-結合と $\beta$-結合の両方の異性体ができるため

Table I. The standard free energy of glucosyl disaccharides and the reaction yield in the reverse hydrolysis reaction and the column system reaction.

\begin{tabular}{cccc}
\hline & & \multicolumn{2}{c}{ Reaction Yield (\%) } \\
\cline { 3 - 4 } Disaccharide & $\Delta \mathrm{G}^{\mathrm{o}}, \mathrm{J} / \mathrm{mol}$ & $\begin{array}{c}\text { Reverse Hydrolysis } \\
\text { Reaction }\end{array}$ & $\begin{array}{c}\text { Column System } \\
\text { Reaction }\end{array}$ \\
\hline Glc $\alpha 1-1 \mathrm{Glc}$ & +6300 & n.d. & n.d. \\
Glc $\alpha 1-2 \mathrm{Glc}$ & +3900 & 1.9 & n.d. \\
Glc $\alpha 1-3 \mathrm{Glc}$ & +4200 & 2.5 & n.d. \\
Glc $\alpha 1-4 \mathrm{Glc}$ & +6200 & 2.2 & 2 \\
Glc $\alpha 1-6 \mathrm{Glc}$ & -2100 & 25 & 0.4 \\
\hline
\end{tabular}




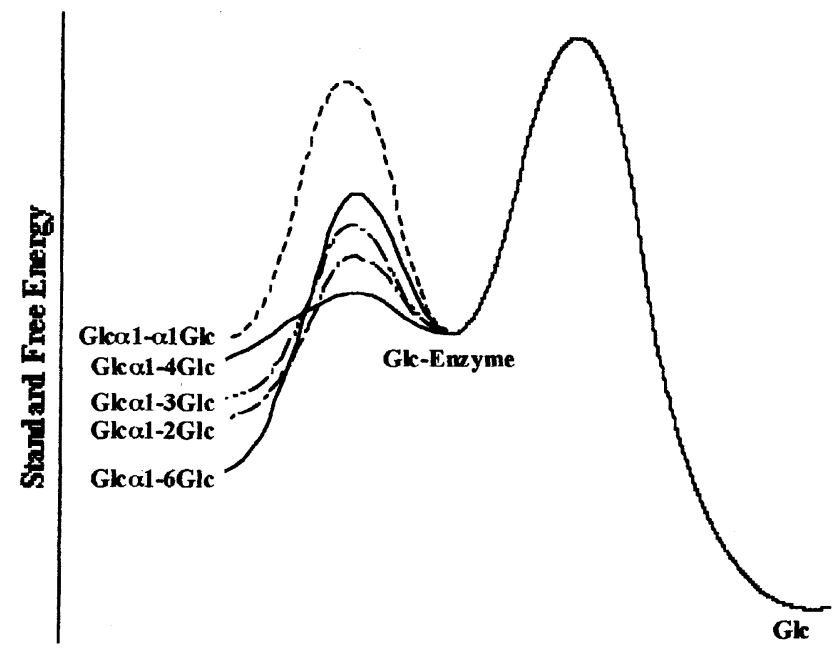

Fig. 2. Schematic demonstration of potential energies of substrate and produced disaccharides.

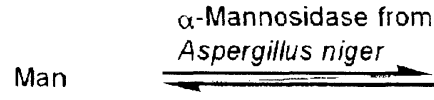

$10 \mathrm{~g}$
$\operatorname{Man}_{\alpha 1-2 M a n+}$

$290 \mathrm{mg}$
$33 \mathrm{mg}$

$2.2 \mathrm{~g}$ $30 \mathrm{mg}$
GICNAC $\beta 1-2$ Man
$73 \mathrm{mg}$

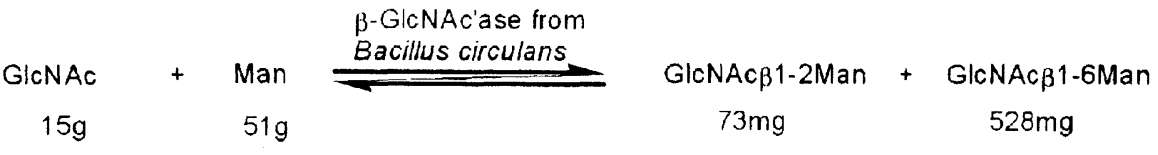

$\alpha$-GalNAc'ase from

GaINAc + Ser

$9 g$
GalNAc $\alpha$-O-Ser

$1.6 \mathrm{~g}$

Fig. 3. Preparative scale syntheses of disaccharides by reverse hydrolysis reaction.

are also formed (data not shown). When the composition of only $\alpha$-linked disaccharides was compared with that of the enzymatic reaction, a parallel tendency was observed; namely, the acid catalyzed oligosaccharide synthesis is also controlled by the level of standard free energy.

We have synthesized various oligosaccharides comprising glycoproteins or glycolipids by reverse hydrolysis reaction. Results are summarized in Fig. 3. As shown in section E, in transglycosylation glycosyl compounds or disaccharides must be used to synthesize oligosaccharides, but in contrast, in reverse hydrolysis reactions free sugars can be used as starting materials. Although purification processes are needed in the reverse hydrolysis reaction since many isomers are produced together,
に複雑な組成となるが、 $\alpha$-系列の 2 糖のみについて比較する

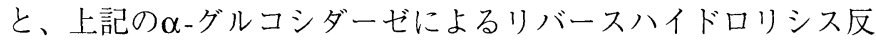
応における生成比と同様の值を示した。即ち酸触媒によるオリ ゴ糖合成反応の場合にも、その組成を決定しているのは最終生 成物の標準自由エネルギーの高低であることを物語っている。

我々はこのような原理に基づいて、複合糖質を構成する種々 のオリゴ糖をリバースハイドロリシス反応により合成した。結 果を図 3 に示す。E節の転移反応の項において詳述する転移反 応では、原料としてオリゴ糖あるいはグリコシド化合物を糖供 与体として用いるのに対し、このリバースハイドロリシス反応 においてはフリーの糖を用いることができるという点が特徴で ある。またリバースハイドロリシス反応は生成物の種類が多い ために精製がやっかいであるが、いくつものオリゴ糖を一挙に 
it can be a merit that many oligosaccharides can be obtained in one reaction. Therefore, if a purification process is developed, the reverse hydrolysis method may be a widely applicable method for commercial synthesis of oligosaccharides.

\section{Column System Reaction; a Versatile Method of Reverse Hydrolysis Reaction}

We have developed a new reaction system, a column system reaction, as a modification of the reverse hydrolysis reaction $(13,14)$. I will demonstrate the reaction using $\alpha$-glucosidase-catalyzed glucose condensation as a model reaction. A highly concentrated glucose solution was circulated continuously through an immobilized $\alpha$-glucosidase column and an activated carbon column connected sequentially as shown in Fig. 4 . In the immobilized $\alpha$-glucosidase column, disaccharides will be produced by the reverse hydrolysis reaction, though the amount may be very small. Here, the nature of disaccharides is such that they are adsorbed on the activated carbon preferentially to monosaccharides, and similarly trisaccharides preferentially to disaccharides. Consequently, the disaccharides formed in the $\alpha$ glucosidase immobilized column were adsorbed in the activated column. Although glucose might be adsorbed in the activated carbon column in the beginning, disaccharides will subsequently be adsorbed and in so doing expel those glucose molecules. Therefore, only glucose comes out of the activated carbon column, and then this glucose is directed into the immobilized $\alpha$ glucosidase column again. As a result, a condensation to form disaccharides is repeated continuously in the immobilized enzyme column, and disaccharides are accumulated in the activated carbon column. In Table I, a result of a column system reaction is also listed. Interestingly, the yield of $\alpha 1-4$-linked disaccharide was higher than that of $\alpha 1-6$-linked isomer in the column system reaction, differing from the batch method reaction.
合成できるという意味では長所でもある。後で述べる転移反応 では合成が難しいオリゴ糖もリバースハイドロリシス反応なら ば合成できる場合もあり、反応液から目的のオリゴ糖を精製し なければならないという条件は付くが、リバースハイドロリシ ス反応は実用的な合成法であるということができる。

\section{D. リバースハイドロリシス反応の別法、カラム法反応}

我々はリバースハイドロリシス反応の応用例として活性炭力 ラムを利用したカラム法反応という手法を開発した $(13 、 14) 。 こ$ のカラム法反応についてもグルコースを用いた反応を例として 説明する。図 4 に示すように、 $\alpha$-グルコシダーゼを固定化した カラムと活性炭カラムを直列に繋ぎ、これにグルコースの高濃 度溶液を循環させる。すると固定化酵素カラム内でリバースハ イドロリシス反応により、微量ではあるが 2 糖が生成するはず である。ところで、活性炭には単糖よりも 2 糖、 2 糖よりも 3 糖をより強く吸着する性質がある。従って、反応液を循環する と最初は活性炭カラムにはグルコースが吸着されるが、固定化 酵素内で生成した 2 糖が活性炭カラムに入ってくると 2 糖がグ ルコースを押し退けて吸着される。従って、活性炭カラムを出 てくる液はグルコースのみの溶液となり、それが循環により再 度固定化酵素カラムに入って、リバースハイドロリシス反応が 繰り返される。即ち、固定化酵素カラム内でリバースハイドロ リシス反応によって生成した 2 糖は全て活性炭カラムに吸着さ れて、固定化酵素カラム内には常に単糖のみが入っていく。そ の結果、固定化酵素カラム内では、リバースハイドロリシス反 応により 2 糖が生成するということが繰り返され、活性炭力ラ 厶内には連続的に 2 糖が蓄積されていくことになる。表 Iには カラム法反応の収率も併せて示してある。興味あることに、リ バースハイドロリシス反応では $\alpha 1-6$ 結合の 2 糖が圧倒的に大き い比率で生成するのに対し、カラム法反応では $\alpha 1-6$ 結合よりも Q1-4結合の 2 糖の方が生成比が大きいことが明らかになった。 この場合にも先に示したエネルギー変化の模式図(図 2 )を利用 して説明することができる。図 2 において、 $\alpha 1-4$ 結合の 2 糖と

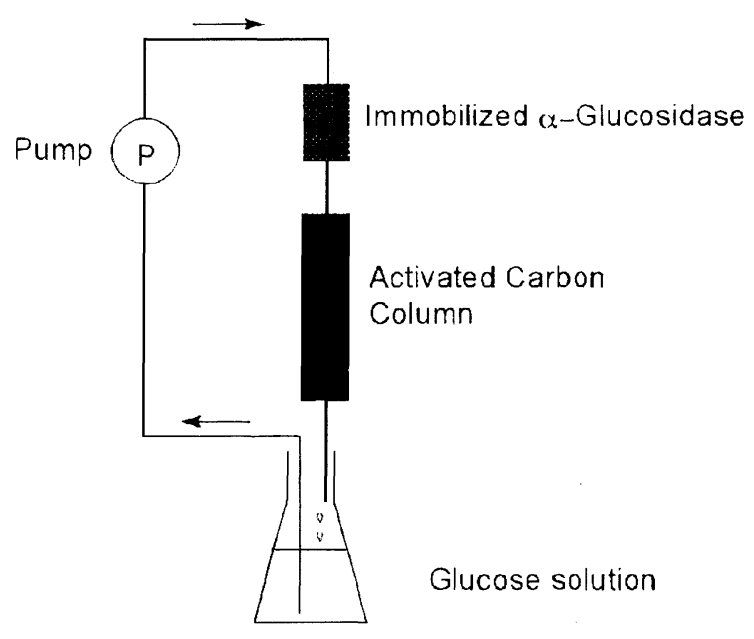

Fig. 4. Column system reaction. 
This result can be explained referring to Fig. 2. The energy barrier of the activation intermediate of $\alpha 1$-4-linked disaccharideenzyme was lower than that of $\alpha 1$-6-linked disaccharide-enzyme. Therefore the formation of $\alpha 1$-4-linked disaccharide is faster than that of $\alpha 1-6$-linked isomer, and the formed disaccharides will be immediately adsorbed in the activated carbon column.

Thus the column system reaction was shown to be able to limit the equilibrium reaction to the very first stage, and the column system reaction can provide a different regioselectivity from the normal reverse hydrolysis reaction.

\section{E. Transglycosylation}

If an acceptor sugar attacks the active intermediate of enzyme-substrate and a new glycosidic bond is formed as a result, the reaction is called a transglycosylation. In Fig. 5, transglycosylation reactions of para-nitrophenyl- $\beta$-D-galactopyranoside $\mathbf{1}$ as a donor and GlcNAc $\mathbf{6}$ as an acceptor are shown using various $\beta$-galactosidases of different origins. In the transglycosylation using $\beta$-galactosidase from Bacillus circulans, commercial name Biolacta $^{\mathrm{TM}}$, Gal $\beta 1-4 \mathrm{GlcNAc} 8$ was obtained regioselectively since this enzyme shows high specificity to $\beta 1$ 4-linked disaccharides (15). In contrast, $\beta$-galactosidase from $E$. coli shows specificity to $\beta 1-6-$ linkage, and the transglycosylation using this enzyme gave Gal $\beta 1-6$ GlcNAc9 regioselectively (26). Bacillus circulans is known to produce four kinds of $\beta$-galactosidases and we have cloned a gene encoding $\beta$-galactosidase specific to $\beta 1$-3-linkage and expressed the enzyme in $E$. coli (16). Transglycosylation using this enzyme afforded Galß1-3GlcNAc 7 or Galß1-3GalNAc derivatives, which are important intermediates for the synthesis of glycoconjugates (17). Other than this enzyme, $\beta$-galactosidase from bovine testis (18), porcine testis (19), and Xanthomonas manihotis (20) hydrolyzes $\beta 1-3$-linkage specifically, and catalyzes the synthesis of $\beta 1-3$-linked disaccharides regioselectively by transglycosylation. Further, $\beta$-galactosidases from
酵素との活性化中間体のエネルギー障壁の方が、 $\alpha 1-6$ 結合の 2 糖と酵素との活性化中間体のエネルギー障壁よりも低いため に、 $\alpha 1-4$ 結合の 2 糖の方が生成速度が速く、生成した 2 糖は直 ちに活性炭カラムに吸着されるためであると説明できる。

このようにカラム法反応は溶液中に扔ける平衡反応におけ る極く初期の段階の反応を固定することができることが示され た。またカラム法反応では、通常のリバースハイドロリシス反 応とは異なる位置選択性を示すことが明らかとなった。

\section{E. 転移反応}

転移反応とは、図1に示したように基質の糖か酵素と活性 化中間体を形成し、それに受容体の糖が攻撃して新たなグリコ シド結合が生成する反応である。パラニトロフェニル- $\beta$-D-ガラ クトピラノシド 1 を糖供与体、GlcNAc 6を糖受容体とした反応 において、いろいろな起源の $\beta$-ガラクトシダーゼを用いて反応 を行うと、酵素の起源の違いにより生成物の構造が異なること が明らかになった(図 5 )。即ち、Biolactaという商品名で市販さ れているBacillus circulans 由来のß-ガラクトシダーゼは、 $\beta 1-4$ 結 合の 2 糖を高い特異性で加水分解するが、転移反応でも高い選 択性でGalb1-4GlcNAc 8を与える(15)。一方E. coli由来の $\beta$-ガラ クトシダーゼは $\beta 1-6$ 結合に高い特異性を示すが、転移反応でも Galb1-6GlcNAc9を与える(26)。B. circulansは 4 種類の $\beta$-ガラク トシダーゼを生産していることが知られているが、我々のグ ループは微量生産されている $11-3$ 結合に特異性の高い $\beta$-ガラクト シダーゼの遺伝子をクローニングして大腸菌で発現させることに 成功した(16)。この酵素を用いて転移反応を行うと、複合糖質糖 鎖の合成中間体として重要なGalß1-3GlcNAc 7あるいはGalß13GalNAc拉よびこれらの誘導体が選択的且つ高収率で得られるこ とを見出した(17)。この他にも $\beta 1-3$ 結合のオリゴ糖を選択的に与 える酵素としては、牛あるいはブ夕精巣由来の酵素 $(18 、 19)$ およ びXanthomonas manihotis 由来の酵素(20)が、また $\beta 1-4$ 結合の才 リゴ糖を与える酵素としては、Bifidobacterium bifidum 由来ある
Products
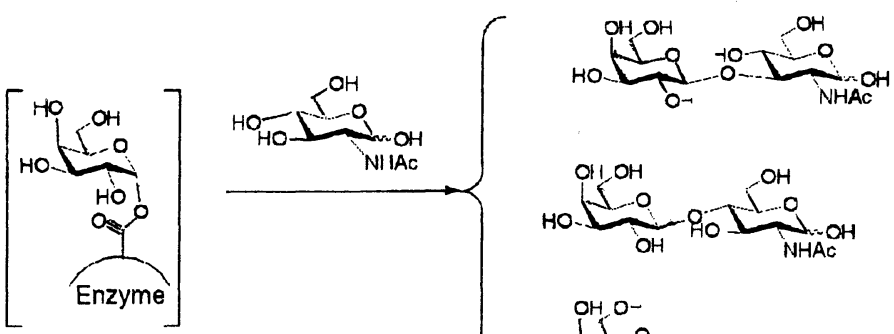

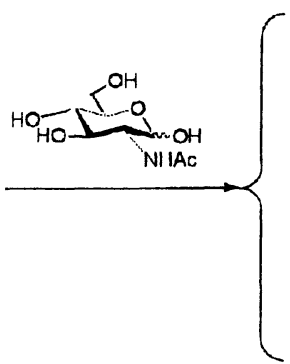

Enzyme

$\beta$-Galactosidase from Bacillus circulans (recombinant)

$\beta$-Galactosidase from Bacillus circulans (Biolacta)

$\beta$-Galactosidase from $E$ coli

Fig. 5. Differences of regioselectivity in the transglycosylation using $\beta$-galactosidases of different origins. 
Bifidobacterium bifidum and Diplococcus pneumoniae are known to give $\beta 1$-4-linked oligosaccharide by transglycosylation (21).

Until now, the regioselectivity in oligosaccharide synthesis using glycosidases has been thought to be very low, but by use of glycosidases showing high specificity in the hydrolysis reaction, the transglycosylation products were shown to be highly regioselective. In Table II, enzymes and examples of the regioselective reaction are summarized.

The transglycosylation using $\alpha$-fucosidase showed interesting results (22). The reaction using $\alpha$-fucosidase from $A s$ pergillus niger gave $\alpha 1-3$-linked disaccharide in the reaction using GlcNAc as an acceptor, but gave no transglycosylation product when galactose was used as an acceptor. In contrast, the reaction using $\alpha$-fucosidase from Arthrobactor ureafaciens gave $\alpha 1$-2-linked disaccharide when galactose was used as an acceptor, but gave no transglycosylation product when GlcNAc was used as an acceptor. Thus in this case the selection of acceptor displayed an important role in the transglycosylation reaction.

Sialidase from Newcastle Disease Virus (NDV) is known to be highly specific to $\alpha 2-3$-linkage and is used for the structural analysis of glycoconjugates. We have shown that NeuAc $\alpha 2-$ 3Gal $\beta 1-4$ GlcNAc could be obtained in the NDV sialidase catalyzed transglycosylation using NeuAc- $\alpha$-pNP as a donor and $\mathrm{N}$-acetyllactosamine as an acceptor (23). Makimura et al also reported that the reaction using sialidase from Salmonella typhimurium gives NeuAc $\alpha 2-3 \mathrm{Gal} \beta 1-4 \mathrm{GlcNAc}$ in high yield (24). Further, the transglycosylation using sialidase from Arthrobactor ureafaciens or Clostridium perfringens was shown to give $\alpha 2-6$-linked oligosaccharides by transglycosylation (23). By these results, it is demonstrated that transglycosylation using sialidase can achieve results similar to those of the equivalent reaction using transferase.

Although a disaccharide or glycoside compound is usu-
いはDiplococcus pneumoniae由来の酵素が知られている(21)。

これまで加水分解酵素を用いたオリゴ糖の合成反応は選択 性が低いことが欠点であるといわれてきた。しかし、上に示し たように加水分解の特異性が高い酵素を用いれば、一種類の才 リゴ糖を選択的に合成できることが明らかになってきた。位置 選択性が高く、オリゴ糖の合成に実用的に利用できる酵素およ び反応を表IIにまとめて示した。

一方、 $\alpha$-フコシダーゼを用いた反応では興味ある結果が得 られた(22)。即ち、Aspergillus niger 由来の酵素を用いた場合に は 1 1-3結合の2糖を与えるが、この場合には GlcNAcを糖受容体 とし、ガラクトースを糖受容体とした場合には反応生成物を与 えない。逆に、Arthrobacter ureafacience 由来の酵素を用いた場 合には $\alpha 1-2$ 結合の 2 糖を与え、この場合にはガラクトースを糖 受容体とし、GlcNAcを糖受容体とする 2 糖は与えない。このよ うに酵素によっては結合の選択性と同時に糖受容体となる糖に 関しても選択性を発揮することがあるということも明らかに なった。

Newcastle Disease Virus由来のシアリダーゼは $\alpha 2-3$ 結合に特 異的なシアリダーゼとして知られており、糖鎖の構造解析にも よく利用されている。我々はNeuAc- $\alpha$-pNPを糖供与体、 $N$-アセ チルラクトサミンを糖受容体として、Newcastle Disease Virus由 来のシアリダーゼを用いて転移反応を行うと、NeuAco2-3Galß14GIcNAcを与えることを見出した(23)。さらに牧村らによって Salmonella typhimurium由来のシアリダーゼを用いて同じ反応を 行った場合にも NeuAc $\alpha 2-3 \mathrm{Gal} \beta 1-4 \mathrm{GlcNAc}$ が収率30\%以上の高 収率で得られることが見出された(24)。一方、Arthrobacter ureafaciensあるいはClostridium perfringens 由来のシアリダーゼを 用いれば、選択的に $\alpha 2-6$ 結合のシアリルオリゴ糖を与えること が分かった(23)。このようにシアリダーゼを用いた転移反応もシ アリルトランスフェラーゼを用いた反応に十分太刀打ちできる ことが示された。

転移反応においては通常 2 糖あるいはグリコシド化合物が

Table II. Examples of highly regioselective transglycosylation reactions.

\begin{tabular}{|c|c|c|c|c|c|}
\hline Donor & Acceptor & Enzyme & Product & Yield & Lit. \\
\hline Gal- $\alpha-p N P$ & Gal & $\alpha$-Galactosidase from Coffea arabica & Gal $\alpha 1-3 \mathrm{Gal}$ & $50 \%$ & 31 \\
\hline Gal- $\alpha-p N P$ & Gal $\alpha 1-6 \mathrm{Glc}$ & $\alpha$-Galactosidase from Aspergillus niger & Gal $\alpha 1-6 \mathrm{Gal} \alpha 1-6 \mathrm{Glc}$ & $30 \%$ & 31 \\
\hline Gal- $\beta$-pNP & GlcNAc & $\beta$-Galactosidase from Bacillus circulans & Gal $\beta 1-3 \mathrm{GlcNAc}$ & $60 \%$ & 16 \\
\hline Gal- $\beta-\mathrm{pNP}$ & GlcNAc & $\beta$-Galactosidase from Bacillus circulans & Galß1-4GlcNAc & $50 \%$ & 15 \\
\hline Gal- $\beta$-pNP & GlcNAc & $\beta$-Galactosidase from Bifidobacterium bifidum & Gal $\beta 1-4 G l c N A c$ & $50 \%$ & 21 \\
\hline Gal- $\beta-p N P$ & GlcNAc & $\beta$-Galactosidase from Eschelichia coli & Gal $\beta 1-6 \mathrm{GlcNAc}$ & $50 \%$ & 26 \\
\hline Fuc- $\alpha-p N P$ & GlcNAc & $\alpha$-Fucosidase from Penicillium multicolor & Fuc $\alpha 1-3$ GlcNAc & $40 \%$ & 27 \\
\hline Fuc- $\alpha-p N P$ & Gal & $\alpha$-Fucosidase from Arthrobactor ureafaciens & Fuc $\alpha 1-2 \mathrm{Gal}$ & $30 \%$ & 22 \\
\hline NeuAc- $\alpha-p N P$ & Gal & Sialidase from Salmonella typhimurium & NeuAc $\alpha 2-3 \mathrm{Gal}$ & $30 \%$ & 24 \\
\hline NeuAc- $\alpha$-pNP & Gal & Sialidase from Newcastle Disease Virus & NeuAc $\alpha 2-3 \mathrm{Gal}$ & $20 \%$ & 23 \\
\hline NeuAc- $\alpha-p N P$ & Gal & Sialidase from Arthrobactor ureafaciens & NeuAc $\alpha 2-6 \mathrm{Gal}$ & $20 \%$ & 23 \\
\hline
\end{tabular}


ally used as the donor in the transglycosylation reaction, Shoda et al reported a unique reaction using oxazoline as a donor. Chitin was synthesized by reacting oxazoline of chitobiose in the presence of chitinase from Bacillus sp. in alkaline solution, after which the chitobiose was linked with $\beta 1$-4-linkage repeatedly to give chitin (25).

\section{F. Control of Regioselectivity in the Transglycosylation}

As shown above, the regioselectivity in the transglycosylation is highly correlated with the specificity in the hydrolysis reaction. However, several exceptions to this rule have been found recently. Two examples are shown below; the transglycosylation using $\alpha$-fucosidase from Penicillium multicolor and a $\beta$-galactosidase from $B$. circulans.

\section{F-1. Transglycosylation Using $\alpha$-fucosidase From $P$. multicolor}

Transglycosylation using $\alpha$-fucosidase from $P$. multicolor afforded a 49\% yield of Fuc $\alpha 1-3 \mathrm{GlcNAc}$ regioselectively using Fuc- $\alpha$-pNP as a donor and GlcNAc as an acceptor $(27,28)$. However, contrary to expectations, $\alpha 1$-3-linked disaccharide was hydrolyzed much more slowly than $\alpha 1$-2-linked and $\alpha 1$-6-linked disaccharides. This hydrolysis result is the reverse to that of transglycosylation. However, the relative rates of hydrolysis of Fuc $\alpha 1-2 G a l$, Fuc $\alpha 1-6$ GlcNAc, and Fuc- $\alpha$-pNP should be noticed. Fuc $\alpha 1-2 \mathrm{Gal}$ and Fuc $\alpha 1-6 \mathrm{GlcNAc}$ were hydrolyzed at approximately the same rate as Fuc- $\alpha-p N P$, but Fuc $\alpha 1-3$ GlcNAc was hydrolyzed at a much slower rate than Fuc- $\alpha-p N P$. The result of the transglycosylation may be explained from the relative hydrolysis rates. That is, the rates of the formation of Fuc $\alpha 1-$ $2 \mathrm{Gal}$ or Fuc $\alpha 1-6 \mathrm{GlcNAc}$ from Fuc- $\alpha-\mathrm{pNP}$ are almost the same
糖供与体として用いられるが、正田らによってその変法ともい うべき興味ある例が報告されている。即ち、キトビオースの才 キサゾリンを糖供与体として用いて、Bacillus 属由来のキチナー ゼを作用させることにより、キトビオースが繰り返し $11-4$ 結合 でつながりキチンが生成することが見出されている(25)。

\section{F. 転移反応における位置選択性のコントロール}

これまで示してきたように、生成するオリゴ糖の結合の選 択性は加水分解の特異性に沿っていることが明らかになってき た。ところが、一見その規則に従わないと思われる例がいくつ か見出されてきた。次にそのような例として、P. multicolor 由来 の -フコシダーゼによる転移反応の例、拈よびB. circulans 由来 の $\beta$-ガラクトシダーゼを用いた反応例について示す。

F-1.P. multicolor 由来の $\alpha$-フコシダーゼを用いた転移反応

Fuc- $\alpha$-pNPを糖供与体、GlcNAcを糖受容体として、P. multicolor由来の $\alpha$-フコシダーゼを用いて転移反応を行うと、 Fuc 1 1-3GlcNAcを49\%の収率で巽択的に与える(27、28)。一方、 種々の結合のフコシルオリゴ糖の加水分解のされやすさを比較 したところ(図 6 )、Fuc 1 1-2Gal および Fuc $\alpha$ 1-6GlcNAc は速く加 水分解され、Fuc 1 1-3GlcNAcに対する加水分解速度はかなり遅 いことが明らかになった。この加水分解の結果は、転移反応で Fuca 1-3GlcNAcが高い選択性で得られるという結果と相反する ものである。しかし、ここで注目しなければならないことは、 糖供与体であるFuc- $\alpha-p N P$ と生成物である 2 糖の相対的な加水分 解速度である。図 6 から Fuc $1-2 \mathrm{Gal}$ と Fuc $\alpha$ 1-6GlcNAc はFuc$\alpha-p N P$ 同じょうな速度で加水分解されるのに対し、Fuc $\alpha 1$ 3GlcNAcはかなり遅いことがわかる。これから、転移反応の結

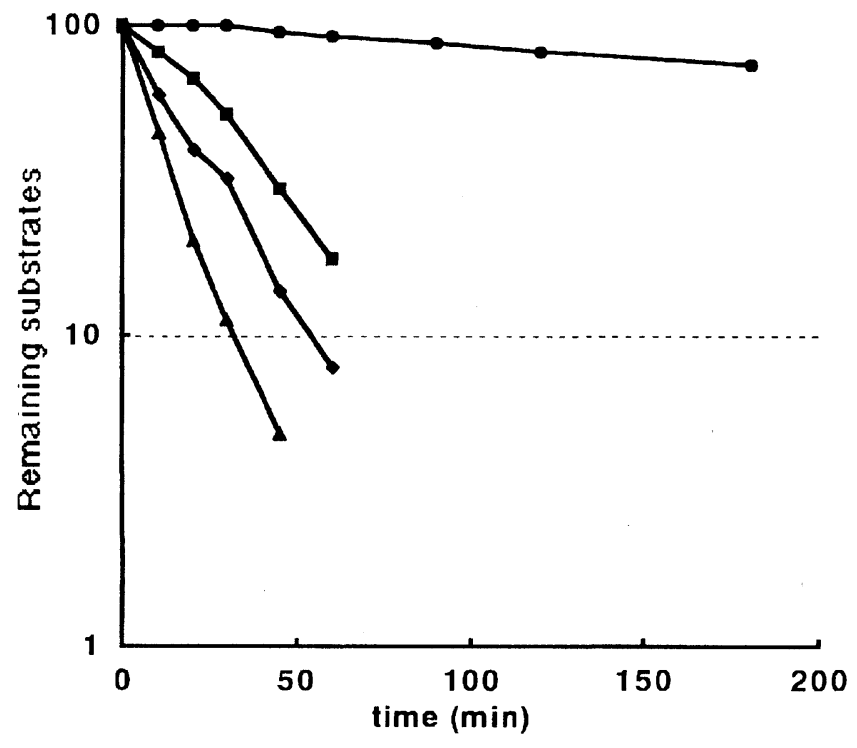

Fig. 6. Relative hydrolysis rate of fucosyl disaccharides and Fuc- $\alpha$-pNP in the presence of $\alpha$-fucosidase from P. multicolor. $\Delta$, Fuc- $\alpha-\mathrm{pNP} ; \diamond$, Fuc $\alpha 1-2 \mathrm{GlcNAc}$; , Fuc $\alpha 1-6 \mathrm{GlcNAc} ; \boldsymbol{\bullet}$, Fuc $\alpha 1-3 \mathrm{GlcN} A \mathrm{c}$. 
as the rates of the hydrolysis of the same, and therefore Fuc $\alpha 1$ $2 \mathrm{Gal}$ and Fuc $\alpha 1-6 \mathrm{GlcNAc}$ are hydrolyzed as soon as they are formed. As a result, Fuc $\alpha 1-2 \mathrm{Gal}$ and Fuc $\alpha$ 1-6GlcNAc do not accumulate in the solution. In contrast, the hydrolysis rate of Fuc $\alpha 1-3$ GlcNAc is much slower than the rate of formation from Fuc- $\alpha-p N P$, and as a result, a large amount of Fuc $\alpha 1-3$ GlcNAc remains in the solution. Therefore the regioselectivity is controlled by not only the relative hydrolysis rates of the target oligosaccharides, but also the relative hydrolysis rates of donor and target oligosaccharides.

\section{F-2. Transglycosylation Using $\beta$-galactosidase From $B$. circulans}

$\beta$-Galactosidase from $B$. circulans catalyzes the hydrolysis of Gal $\beta 1-3 \mathrm{GlcNAc}$ specifically, and the enzyme has been reported to produce Gal $\beta 1-3 \mathrm{GlcNAc}$ regioselectively by transglycosylation from Gal- $\beta$-pNP and GlcNAc (17). However, recently, Gal $\beta 1-6-$ Gal 12 was found to be obtained preferentially in the reaction using galactose $\mathbf{1 1}$ as an acceptor as shown in Fig. 7 (29).

In order to clarify this mechanism, we have synthesized various galactosyl disaccharides and compared the hydrolysis rates of the disaccharides. Results are summarized in Table III. The rates of hydrolysis of Gal $\beta 1-3 \mathrm{GlcNAc}, \mathrm{Gal} \beta 1-3 \mathrm{GalNAc}$, and those derivatives are faster than those of corresponding $\beta 1$ 4-linked or $\beta$ 1-6-linked disaccharide derivatives. Further, in the case of Gal-Gal and its derivatives, $\beta 1-6-$ linkage was hydrolyzed faster than $\beta 1$-3-linkage or $\beta 1$-4-linkage. Therefore, in this case, the regioselectivity can be explained by the general rule of hydrolysis rate correlating with the regioselectivity in transglycosylation. But it is not clear why the specificity in hydrolysis changes with the difference of aglycon structure in galactosyl disaccharides. Concerning the mechanism of this phenomenon Usui et al have suggested that the steric circumstances of galactose and GalNAc molecule in the enzyme pocket (29)
果は次のように説明される。即ち、Fuc- $\alpha$-pNP から Fuc $\alpha$ 1-2Gal あるいは Fuc $\alpha$ 1-6GlcNAc が生成する速度と、それらが加水分解 される速度が同程度であるために、Fuc 1 1-2Gal および Fuc $\alpha$ 16GlcNAc は生成するや否や加水分解されてしまい、結果として 蓄積されないものと解釈される。一方、Fuc $\alpha$ 1-3GlcNAc は生成 する速度は Fuc- $\alpha$-pNPの加水分解速度によって決定されるため に速く生成するが、加水分解される速度が遅いために加水分解 されずに残った量が多かったものと解粕できる。従って、単に 目的の結合に対する特異性が高いか低いかという点だけではな く、糖供与体の加水分解速度との相対的な比較が重要であるこ とが明らかになった。

F-2. B. circulans由来の $\beta$-ガラクトシダーゼを用いた転移反応 我々が開発したBacillus circulans 起源のリコンビナント $\beta$-ガ ラクトシダーゼは、高い特異性でGalß1-3GlcNAcを加水分解 し、転移反応に扔いてもこの 2 糖が選択的に得られることを報 告してきた(17)。ところが最近、ガラクトース11を糖受容体とし て用いると、Galß1-6Gal 12が選択的に形成されることが見出さ れた(29)。(図 7 )

そこでその原因を解明する目的でいろいろなガラクトシル 2 糖を合成して、それらの加水分解速度の比較を行った。結果 を表IIIに示す。表IIIから分かるように、Galß1-3GlcNAcあるい はGalß1-3GalNAcおよびこれらの誘導体の加水分解速度は相当 する $\beta 1$-4結合あるいは $\beta 1-6$ 結合の 2 糖誘導体の加水分解速度よ りも速く、逆にGal-Galおよびその誘導体の場合には $\beta 1-6$ 結合の 方が $\beta 1$-3結合あるいは 1 - 4 結合の 2 糖誘導体の加水分解速度よ りも速いことが明らかになった。従ってB. circulans由来の $\beta$-ガ ラクトシダーゼの場合には、加水分解速度と転移反応の生成速 度に関する一般則から説明できることが示された。しかし、還 元末端側の糖がGlcNAcあるいは GalNAc からガラクトースに変 わるのみで加水分解の特異性がこのように劇的に変化する理由 については不明である。碓水らによって、酵素の活性部位内で のガラクトース分子あるいはGalNAc分子の立体的環境が異なる ことによってこのような現象が起こるのではないかと推察され ている(29)。

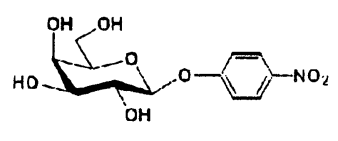

1
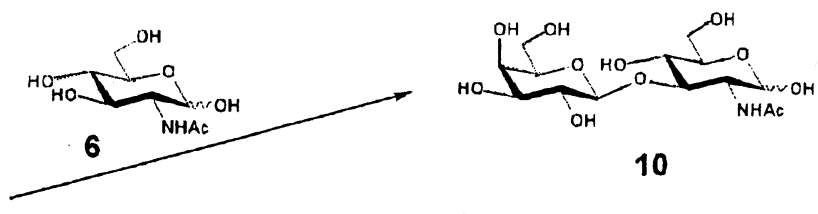

10

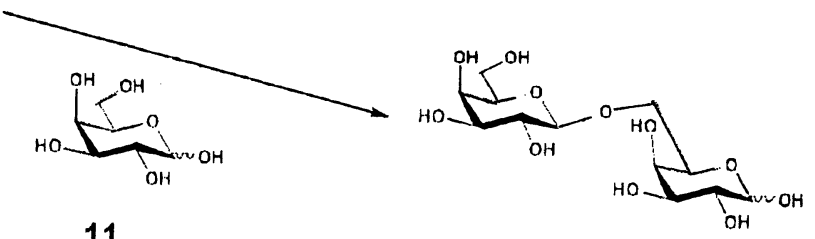

12

Fig. 7. Difference of regioselectivity in the transglycosylation using different acceptors. 
Table III. Hydrolysis velocity of glycosides and disaccharides containing $\beta$ linked galactosyl residue in the presence of $\beta$-galactosidase from $B$. circulans.

\begin{tabular}{|c|c|}
\hline Oligosaccharides & $\mu \mathrm{mol} / \mathrm{min} / \mathrm{mg}$ \\
\hline Gal- $\beta-p$ NP & 93.4 \\
\hline Gal- $\beta-(1 \rightarrow 3)$-GalNAc & 81.3 \\
\hline Gal- $\beta-(1 \rightarrow 3)-G l c N A c$ & 58.0 \\
\hline Gal- $\beta-(1 \rightarrow 6)-G a l$ & 4.7 \\
\hline Gal- $\beta-(1 \rightarrow 6)-$ Gal- $\alpha-O M e$ & 5.6 \\
\hline Gal- $\beta-(1 \rightarrow 6)-G a l-\beta-O M e$ & 4.8 \\
\hline Gal- $\beta-(1 \rightarrow 6)-G l c N A c$ & 4.5 \\
\hline Gal- $\beta-(1 \rightarrow 6)-$ GalNAc & 4.6 \\
\hline Gal- $\beta-(1 \rightarrow 3)-$ Gal- $\alpha-O M e$ & 1.5 \\
\hline Gal- $\beta-(1 \rightarrow 3)-$ Gal- $\beta-O M e$ & 1.6 \\
\hline Gal- $\beta-(1 \rightarrow 4)-G a l-\alpha-O M e$ & $<1$ \\
\hline Gal- $\beta-(1 \rightarrow 4)-G a l-\beta-O M e$ & $<1$ \\
\hline Gal- $\beta-(1 \rightarrow 4)-$ GalNAc & $<1$ \\
\hline Gal- $\beta-(1 \rightarrow 4)-G l c$ & $<1$ \\
\hline Gal- $\beta$-OMe & $<1$ \\
\hline
\end{tabular}

are involved. At any rate, in using this enzyme the structure determination of sugar chains should be given due consideration.

\section{G. Conclusion}

The regioselectivity in the enzymatic synthesis of oligosaccharides using glycosidase has been thought to be low so that the reaction yield is also low. However as demonstrated above, if one selects the enzyme appropriately, one can obtain target oligosaccharides regioselectively and with high yield, exceeding 50\% in some cases. In addition, the advantage of this method is that the substrates and enzyme are usually not expensive.

Moreover, thanks to recent protein engineering techniques, the hydrolysis activity has been decreased and the transglycosylation activity increased by changing Glu-358 to Ala in $\beta$-glucosidase (30). This technology can be expected to help find and develop industrially useful enzymes.

In summary, it is important to choose the method and enzyme appropriately for the synthesis of a target oligosaccharide regioselectively and with high yield.
いずれにせよ、本酵素を糖鎖構造解析に利用する際には注 意を要することが明らかになった。

G. おわりに

従来、加水分解酵素を利用するオリゴ糖合成法は、生成物 の位置選択性が低く且つ収率も低いことが欠点であるといわれ てきた。しかし、上に述べたように酵素の選択さえ適切なら ば、目的の結合のオリゴ糖を選択的に且つ50\%を越える収率で 合成することも可能となってきた。さらに、この方法の利点 は、基質および酵素が安価で容易に手に入るということであ る。さらに最近、タンパク質工学を利用して $\beta$-グルコシダーゼ の358番目のグルタミン酸をアラニンに変換することにより、加 水分解活性を減少させ、転移活性のみを残すという画期的な酵 素の改造も報告されている(30)。この方法をさらに発展させて、 工業的生産に寄与できるような酵素の開発が期待される。

以上に示してきたことから言えることは、目的のオリゴ糖 を効率的に合成するには、それに適した方法と酵素を組み合わ せていくことが重要であろうと思われる。

謝 辞

本研究の一部は、通産省(現経済産業省)の産業科学技術研究 開発制度の一環として、新エネルギー・産業技術総合開発機構 より委託を受けて実施したものである。 


\section{References}

1. Voragen, A.G.J. and Pilnik, W. (1989) ACS Symposium Series 389, Eds. Whitaker, J.R. and Sonnet, Ph. E. 93-115

2. Hidaka, H., Eida, T., Hashimoto, K., and Nakazawa, T. (1987) Eur. Patent, 0,133,547

3. Ichikawa, Y., Look, G.C., Wong, C.-H.(1992) Anal. Biochem. 202, 215-238

4. Thiem, J. (1995) FEMS Microbiol. Rev. 16, 193-211

5. Watt, G.M., Lowden, P.A.S., and Flitsch, S.L. (1997) Current Opinion in Structural Biol. 7, 652-660

6. Fernandez-Mayoralas, A. (1997) Topics Current Chem. 186, 1-20

7. Crout, D.H.G. and Vic, G. (1998) Curr. Opinion Chem. Biol. 2, 98-111

8. Fujimoto, H., Nishida, H., and Ajisaka, K. (1988) Agric. Biol. Chem. 52, 1345-1351

9. Nikolov, Z. L., Meagher, M. M., and Reilly, P. J. (1989) Biotechnol. Bioeng. 34, 694-704

10. Ajisaka, K., Matsuo, I., Isomura, M., Fujimoto, H., Shirakabe, M., and Okawa, M. (1995) Carbohydr. Res. 270, 123-130

11. Fujimoto, H., Isomura, M., Miyazaki, T., Matsuo, I., Walton, R., Sakakibara, T., and Ajisaka, K. (1997) Carbohydr. Res. 14, 75-80

12. Naundorf, A. and Ajisaka, K. (1999) Enzyme Microb. Technol. 25, 483-488

13. Ajisaka, K., Nishida, H., and Fujimoto, H. (1987) Biotechnol. Lett. 9, 387-392

14. Fujimoto, H. and Ajisaka, K. (1988) Biotechnol. Lett. 10, 107-112

15. Sakai, S., Katsumi, R., Ohi, H., Usui, T., and Ishido, Y. (1992) J. Carbohydr. Chem. 11, 553-565

16. Ito, Y. and Sasaki, T. (1997) Biosci. Biotechnol. Biochem. 61, 1270-1276

17. Fujimoto, H., Miyasato,M., Ito, Y., Sasaki, T., and Ajisaka, K. (1998) Glycoconj. J. 15, 155-160

18. Hedbys, L., Johansson, E., Mosbach, K., and Larsson, P.-O. (1989) Carbohydr. Res. 186, 217-223

19. Murata, T., Ito, T., Hayakawa, Y., and Usui, T. (1996) J. Biochem. 200, 851-855

20. Fujimoto, H. (1997) J. Carbohydr. Chem. 16, 967-970

21. Yoon, Y. -H., and Ajisaka, K. (1996) Carbohydr. Res. 292, 153-163

22. Ajisaka, K. and Shirakabe, M. (1992) Carbohydr. Res. 224, 291-299

23. Ajisaka, K., Fujimoto, H., and Isomura, M. (1994) Carbohydr. Res. 259, 103-115

24. Makimura, Y., Ishida, H., Kondo, A., Hasegawa, A., and Kiso, M. (1998) J. Carbohydr. Chem. 17, 975-979

25. Kobayashi, S., Kiyosada, T., and Shoda, S. (1996) J. Am. Chem. Soc. 118, 13113-13115

26. Kuhn, R., Baer, H.H., and Gauhe, A. (1955) Chem. Ber. 188, 1713-1716

27. Ajisaka, K., Fujimoto, H., and Miyasato, M. (1998) Carbohydr. Res. 309, 125-129

28. Farkas, E., Thiem, J., and Ajisaka, K. (2000) Carbohydr. Res. 328, 293-299

29. Zeng, X., Yoshino, R., Murata, T., Ajisaka, K., and Usui, T. (2000) Carbohydr. Res. 325, 120-131

30. Wang, Q., Graham, R.W., Trimbur, D., Warren, R.A.J., and Withers, S.G. (1994) J. Ame. Chem. Soc. 116, 11594-11595

31. Vic, G., Scigelova, M., Hastings, J.J., Howarth, O.W., and Crout, D.H.G., (1996) Chem. Commun. 1473-1474

Received on October 4, 2001, accepted on October 25, 2001

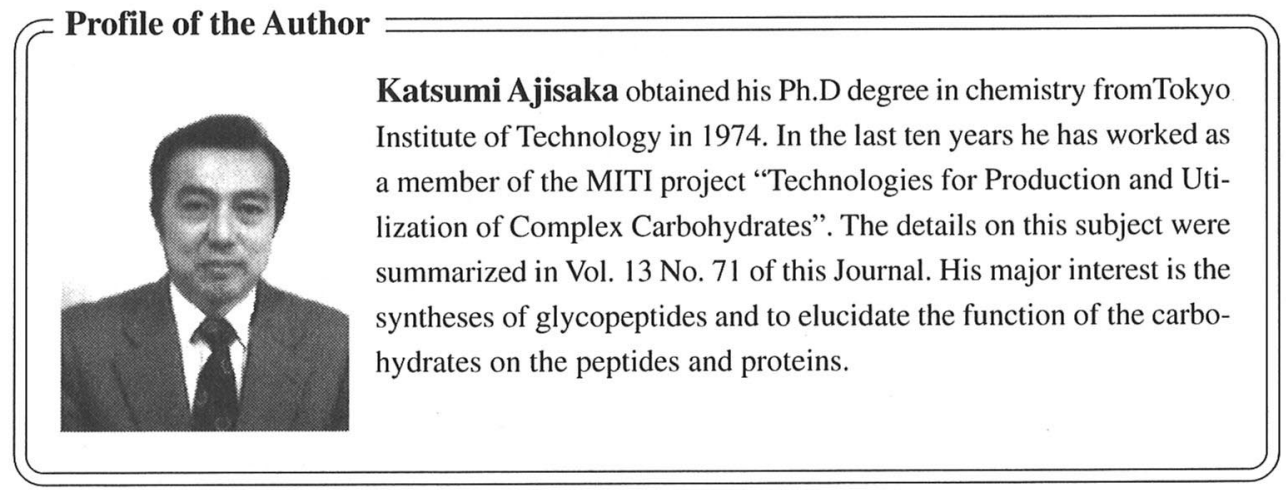

